\title{
Effect of Methanolic Extract in Ointment and Powder of Kalanchoe Pinnata (Lamk) Leaf in Ointment towards Incision Wound Healing in Mice
}

\author{
Adi K. Suprapto ${ }^{1}$, Fen Tih $^{2}$, Endang Evacuasiany ${ }^{3}$ \\ ${ }^{1}$ Faculty of Medicine, Maranatha Christian University \\ ${ }^{2}$ Department of Biochemistry, Faculty of Medicine, Maranatha Christian University \\ ${ }^{32}$ Department of Pharmacology, Faculty of Medicine, Maranatha Christian University \\ Jl. Prof. Drg. Suria Sumantri MPH No.65 Bandung 40164 Indonesia \\ Email: endang.eva49@gmail.com
}

\begin{abstract}
Wound is a very common thing that can happen to all people around the world. The purpose of this study is to investigate the effect of methanolic extract and powder of Kalanchoe pinnata (Lamk) leaf in ointment. The methodology is laboratoric experimental design. Six groups of mice $(n=30)$ were incised for $8 \mathrm{~mm}$ and treated with different treatment: methanolic extract of Kalanchoe pinnata (Lamk) leaves in ointment (SEMDSB) 10\%, SEMDSB 20\%, Kalanchoe pinnata (Lamk) leaves powder in ointment (SSDSB) 10\%, SSDSB 20\%, vaseline album (ointment) as negative control, and povidone iodine ointment as positive control. Examination is carried out by measuring the width of wounds in mice every day until the wound interlocked. Data analysis used one way ANOVA continued by Tukey HSD with $\alpha=0,05$. The result showed the average time for wound healing (in days) are: SEMDSB 10\% (7.2), SEMDSB $20 \%$ (6.6), SSDSB $10 \%$ (8.8), SSDSB $20 \%$ (7.6), negative control (10.6), and positive control (7.8). SEMDSB 10\%, SEMDSB 20\%, and SSDSB $20 \%$ showed highly significant difference ( $p$ $=0,000)$ and SSDSB $10 \%$ showed significant difference $(p=0,021)$ when compared to negative control. As conclusion, methanolic extract and powder of Kalanchoe pinnata (Lamk) leaves in ointment can accelerate wound healing time.
\end{abstract}

Keywords: ointment, Kalanchoe pinnata (Lamk), wound healing, mice 


\title{
Efek Salep Ekstrak Metanol dan Salep Serbuk Daun Cocor Bebek (Kalanchoe Pinnata (Lamk)) terhadap Penyembuhan Luka Sayat pada Mencit
}

\author{
Adi K. Suprapto ${ }^{1}$, Fen Tih $^{2}$, Endang Evacuasiany ${ }^{3}$ \\ ${ }^{1}$ Fakultas Kedokteran, Universitas Kristen Maranatha \\ ${ }^{2}$ Bagian Biokimia, Fakultas Kedokteran, Universitas Kristen Maranatha \\ ${ }^{3}$ Bagian Farmakologi, Fakultas Kedokteran, Universitas Kristen Maranatha \\ Jl. Prof. Drg. Suria Sumantri MPH No.65 Bandung 40164 Indonesia \\ Email: endang.eva49@gmail.com
}

\begin{abstract}
Abstrak
Luka merupakan hal yang dapat dialami semua orang di seluruh dunia. Penelitian ini bertujuan untuk mengetahui efek salep ekstrak metanol dan salep serbuk daun sosor bebek (Kalanchoe pinnata (Lamk)) dalam mempercepat waktu penyembuhan luka. Metodologi penelitian bersifat eksperimental laboratorik. Pada enam kelompok mencit $(n=30)$ dibuat luka sayat sepanjang $8 \mathrm{~mm}$ dan setiap kelompok diberi perlakuan yang berbeda yaitu pemberian salep ekstrak metanol daun sosor bebek (SEMDSB) 10\%, SEMDSB 20\%, salep serbuk daun sosor bebek (SSDSB) 10\%, SSDSB 20\%, vaselin album (ointment) sebagai kontrol negatif, dan povidone iodine ointment sebagai kontrol positif. Data yang diamati adalah lama penyembuhan luka dalam hari hingga luka menutup sempurna, yang ditandai dengan bertautannya kedua tepi luka. Analisis data menggunakan ANOVA satu arah, dilanjutkan uji Tukey $H S D$ dengan $\alpha=$ 0,05 . Rerata waktu penyembuhan luka dalam hari: SEMDSB $10 \%(7,2)$, SEMDSB $20 \%(6,6)$, SSDSB $10 \%(8,8)$, SSDSB $20 \%(7,6)$, kontrol negatif $(10,6)$ dan kontrol positif $(7,8)$. SEMDSB $10 \%$, SEMDSB $20 \%$, SSDSB $20 \%$ berbeda sangat signifikan $(\mathrm{p}=0,000)$ dan SSDSB $10 \%$ berbeda signifikan $(\mathrm{p}=0,021)$ dibandingkan dengan kontrol negatif. Simpulan adalah salep ekstrak metanol dan salep serbuk daun sosor bebek (Kalanchoe pinnata (Lamk)) mempercepat waktu penyembuhan luka.
\end{abstract}

Kata kunci: salep, daun sosor bebek, Kalanchoe pinnata (Lamk), penyembuhan luka, mencit 


\section{Research Article}

\section{Pendahuluan}

Luka adalah hilang atau rusaknya sebagian jaringan tubuh. Luka berakibat hilangnya integritas jaringan yang menyebabkan terlibatnya pembuluh darah, aktivitas sel, dan trombosit untuk memperbaiki integritas jaringan yang rusak. Luka dapat disebabkan oleh trauma benda tajam atau tumpul, perubahan suhu, zat kimia, ledakan, sengatan listrik, atau gigitan hewan. Luka sering terjadi dalam kegiatan sehari-hari. Berdasarkan jenisnya, luka dapat dibagi menjadi 3 jenis yaitu luka akut, luka bakar, dan luka kronik. ${ }^{1,2,3}$

Luka terbuka yang tidak diobati memiliki potensi untuk mengalami infeksi seperti gangren dan tetanus. ${ }^{4}$ Jika infeksi dibiarkan, akan menyebabkan kelumpuhan, infeksi kronik, infeksi tulang, bahkan kematian. Luka yang terinfeksi merupakan penyakit yang paling sering ditemukan pada negara berkembang karena higiene yang kurang baik. Penanganan yang tepat sangat diperlukan untuk mengurangi terjadinya infeksi pada suatu luka.,

Ketersediaan obat yang dapat mempercepat proses penyembuhan luka masih terbatas meskipun perkembangan industri obat sudah sangat maju. Penelitian mengenai zat yang dapat mempercepat penyembuhan luka merupakan salah satu hal yang sedang berkembang dan banyak dilakukan oleh para peneliti dan praktisi tradisional di seluruh dunia khususnya di India dan China. Menurut WHO, $80 \%$ populasi di negara Asia dan Afrika menggunakan cara pengobatan tradisional yaitu obat herbal karena lebih murah, lebih mudah didapat, dan efek samping yang rendah. ${ }^{7}$

Tanaman sosor bebek (Kalanchoe pinnata (Lamk)) berasal dari Madagaskar kemudian tersebar di daerah tropis. Tanaman ini sering ditanam di pekarangan rumah sebagai tanaman hias. ${ }^{8}$ Masyarakat Nigeria menggunakan tanaman ini untuk membantu pelepasan tali pusat pada bayi yang baru lahir, infeksi jamur pada kulit, bronkitis kronik, pneumonia, asma, penyembuhan luka, batu ginjal, dan lain-lain. ${ }^{9}$ Pemberian ekstrak etanol daun sosor bebek secara topikal pada luka hewan percobaan (tikus) meningkatkan aktivitas penyembuhan luka karena adanya kandungan senyawa bufadienolide yang merupakan suatu steroidal glycoside, senyawa saponin, tannin, dan flavonoid..$^{10,11}$

Penelitian ini menggunakan ekstrak metanol karena metanol merupakan pelarut yang paling banyak digunakan dalam proses isolasi senyawa organik bahan alam dan dapat melarutkan golongan metabolit sekunder. Metanol dapat melarutkan hampir semua senyawa organik, baik polar maupun non polar. Selain itu, metanol memiliki struktur molekul kecil yang mampu menembus semua jaringan tanaman untuk menarik senyawa aktif keluar, dan harganya lebih murah daripada etanol. ${ }^{12}$ Sediaan salep serbuk daun sosor bebek dipilih karena pada 


\section{Research Article}

penggunaan untuk penyembuhan luka secara tradisional dilakukan dengan cara diparut atau ditumbuk, kemudian ditambah dengan sedikit air, lalu dioleskan pada bagian tubuh yang luka. ${ }^{13}$

Tujuan penelitian ini adalah untuk mengetahui efek salep ekstrak metanol dan salep serbuk daun sosor bebek dalam mempercepat waktu penyembuhan luka sayat pada mencit.

\section{Metode}

Penelitian ini bersifat eksperimental laboratorik, komparatif, dengan desain Rancangan Acak Lengkap (RAL). Subjek penelitian adalah 30 ekor mencit galur Swiss Webster jantan, berumur 8-9 minggu dengan berat badan antara 25-30 gram, diperoleh dari Laboratorium Perkembangan Hewan Sekolah Farmasi Institut Teknologi Bandung (ITB). Mencit dipelihara dalam wadah plastik dengan penutup kawat, diberi makan pelet dan minum air suling.

Daun sosor bebek diambil dari kecamatan Cicendo, Bandung. Ekstrak metanol dan serbuk daun sosor bebek diperoleh dari Sekolah Ilmu dan Teknologi Hayati, Institut Teknologi Bandung. Vaseline album dan povidone iodine didapat dari salah satu apotik di Bandung.

Mencit dibagi menjadi 6 kelompok, diberi perlakuan berupa sayatan dengan pisau bedah steril pada regio femoris dextra posterior sepanjang $8 \mathrm{~mm}$ dengan kedalaman $\pm 1 \mathrm{~mm}$. Masingmasing kelompok diberi perlakuan yang berbeda yaitu salep ekstrak metanol daun sosor bebek (SEMDSB) 10\%, SEMDSB 20\%, salep serbuk daun sosor bebek (SSDSB) 10\%, SSDSB 20\%, vaseline album (kontrol negatif) dan povidone iodine (kontrol positif). Perlakuan diberikan satu kali per hari secara topikal menggunakan kapas lidi. Setiap hari panjang luka diukur sampai kedua tepi luka sayatan bertautan.

Data yang diperoleh adalah rata-rata lama penyembuhan luka dalam hari hingga luka menutup sempurna, kemudian dianalisis menggunakan ANAVA satu arah, dilanjutkan uji Tukey $H S D(\alpha=0,05)$, dengan nilai kemaknaan berdasarkan nilai $p<0,05$.

Penelitian dilaksanakan di Laboratorium Farmakologi, Fakultas Kedokteran Universitas Kristen Maranatha, Bandung pada bulan Oktober hingga Desember 2012.

\section{Hasil}

Rerata waktu (dalam hari) penyembuhan luka pada keenam kelompok perlakuan dapat dilihat pada gambar. 


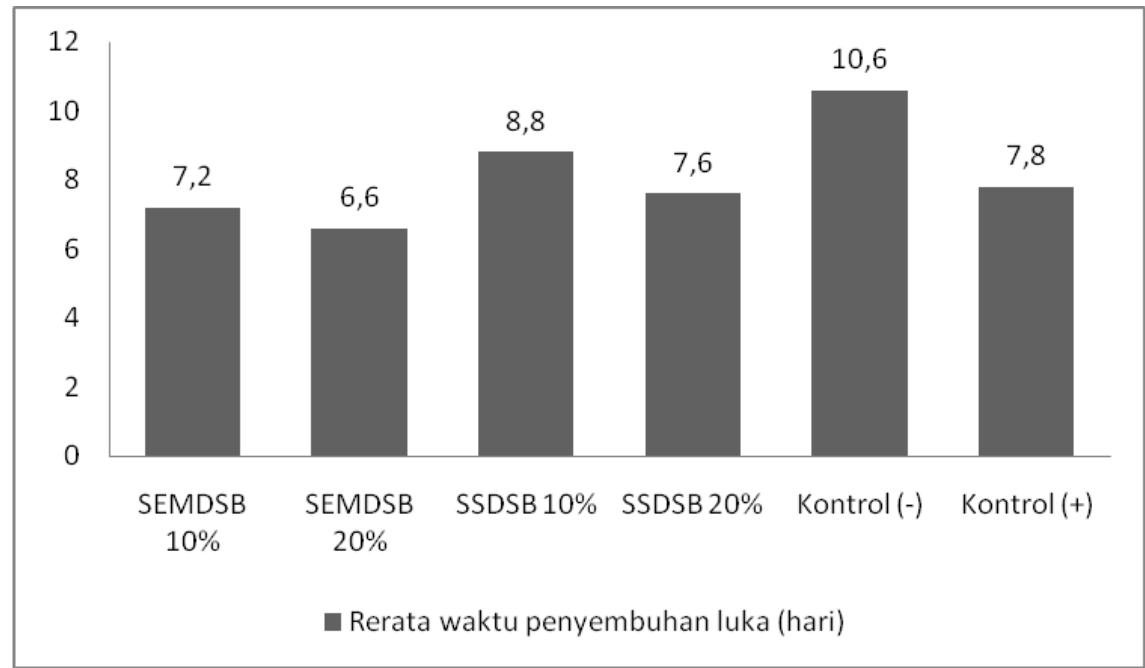

\section{Gambar Grafik Rerata Waktu Penyembuhan Luka Sayat pada Mencit (dalam hari)}

\section{Keterangan:}

1. Kelompok SEMDSB 10\%: diberi salep ekstrak metanol daun sosor bebek $10 \%$

2. Kelompok SEMDSB 20\%: diberi salep ekstrak metanol daun sosor bebek $20 \%$

3. Kelompok SSDSB 10\%: diberi salep serbuk daun sosor bebek $10 \%$

4. Kelompok SSDSB 20\%: diberi salep serbuk daun sosor bebek $20 \%$

5. Kelompok kontrol negatif: diberi vaseline album

6. Kelompok kontrol positif: diberi povidone iodine ointment

Hasil penelitian menunjukkan waktu penyembuhan luka pada keenam kelompok perlakuan berkisar antara 6,6 sampai 10,6 hari. Bila dibandingkan dengan kontrol negatif, semua kelompok yang diberi serbuk daun sosor bebek menunjukkan waktu penyembuhan luka yang lebih cepat, sedangkan bila dibandingkan dengan kontrol positif, kelompok SEMDSB 10\%, SEMDSB 20\%, dan SSDSB 20\% memiliki waktu penyembuhan luka yang lebih cepat. Waktu penyembuhan paling cepat diperoleh pada pemberian SEMDSB $20 \%$.

Analisis secara statistik dengan uji Anova satu arah didapatkan nilai p=0,000 $(<0,01)$, kemudian analisis dilanjutkan dengan uji Tukey $\operatorname{HSD}(\alpha=0,05)$. Hasil analisis ditampilkan dalam tabel.

Tabel Tukey HSD menunjukkan perbedaan yang sangat signifikan antara rerata waktu penyembuhan luka kelompok SEMDSB 10\%, SEMDSB 20\%, dan SSDSB 20\% dibandingkan dengan kontrol negatif, dengan nilai $p=0,000$. Kelompok SSDSB $10 \%$ berbeda secara signifikan dengan kontrol negatif $(p=0,021)$. Salep ekstrak metanol dan serbuk daun sosor bebek dapat mempercepat waktu penyembuhan luka dibandingkan perlakuan vaseline album. 
Tabel Uji Tukey HSD terhadap Waktu Penyembuhan Luka (Hari)

\begin{tabular}{|c|c|c|c|c|c|c|}
\hline KELOMPOK & $\begin{array}{c}\text { SEMDSB } \\
10 \% \\
(7,2)\end{array}$ & $\begin{array}{c}\text { SEMDSB } \\
20 \% \\
(6,6)\end{array}$ & $\begin{array}{c}\text { SSDSB } \\
10 \% \\
(8,8)\end{array}$ & $\begin{array}{c}\text { SSDSB } \\
20 \% \\
(7,6)\end{array}$ & $\begin{array}{c}\text { Kontrol (- } \\
) \\
(10,6)\end{array}$ & $\begin{array}{c}\text { Kontrol } \\
(+) \\
(7,8)\end{array}$ \\
\hline $\begin{array}{c}\text { SEMDSB } 10 \% \\
(7,2)\end{array}$ & & $\begin{array}{c}\mathrm{NS} \\
\mathrm{p}=0,850\end{array}$ & $\begin{array}{c}* \\
\mathrm{p}=0,049\end{array}$ & $\begin{array}{c}\mathrm{NS} \\
\mathrm{p}=0,969\end{array}$ & $\begin{array}{c}* * \\
\mathrm{p}=0,000\end{array}$ & $\begin{array}{c}\mathrm{NS} \\
\mathrm{p}=0,850\end{array}$ \\
\hline $\begin{array}{c}\text { SEMDSB } 20 \% \\
(6,6)\end{array}$ & & & $\begin{array}{c}* * \\
\mathrm{p}=0,03\end{array}$ & $\begin{array}{c}\mathrm{NS} \\
\mathrm{p}=0,406\end{array}$ & $\begin{array}{c}* * \\
\mathrm{p}=0,000\end{array}$ & $\begin{array}{c}\mathrm{NS} \\
\mathrm{p}=0,223\end{array}$ \\
\hline $\begin{array}{c}\text { SSDSB } 10 \% \\
(8,8)\end{array}$ & & & & $\begin{array}{c}\mathrm{NS} \\
\mathrm{p}=0,223\end{array}$ & $\begin{array}{c}* \\
\mathrm{p}=0,021\end{array}$ & $\begin{array}{c}\text { NS } \\
p=0,406\end{array}$ \\
\hline $\begin{array}{c}\text { SSDSB 20\% } \\
(7,6)\end{array}$ & & & & & $\begin{array}{c}* * \\
\mathrm{p}=0,000\end{array}$ & $\begin{array}{c}\mathrm{NS} \\
\mathrm{p}=0,999\end{array}$ \\
\hline $\begin{array}{c}\text { Kontrol (-) } \\
(10,6)\end{array}$ & & & & & & $\begin{array}{c}* * \\
\mathrm{p}=0,000\end{array}$ \\
\hline $\begin{array}{c}\text { Kontrol (+) } \\
\quad(7,8)\end{array}$ & & & & & & \\
\hline
\end{tabular}

Uji Tukey HSD juga menunjukkan rerata waktu penyembuhan luka kelompok SEMDSB 10\% ( $p=0,850$ ), SEMDSB 20\% (nilai $p=0,223$ ), SSDSB $10 \%$ (nilai $p=0,406$ ), dan SSDSB $20 \%$ (nilai $p=0,999$ ) dibandingkan dengan kontrol positif tidak terdapat perbedaan yang signifikan. Dengan demikian, SEMDSB 10\%, SEMDSB 20\%, SSDSB 10\%, dan SSDSB $20 \%$ memiliki potensi yang setara dengan povidone iodine dalam penyembuhan luka.

SEMDSB $10 \%$ memiliki potensi yang setara dengan SEMDSB $20 \% \quad(p=0,850)$, sedangkan SEMDSB 10\% lebih berpotensi dibandingkan SSDSB 10\% ( $p=0,049)$. SEMDSB $20 \%$ dibandingkan dengan SSDSB 10\% menunjukkan adanya perbedaan yang sangat signifikan dengan $p=0,003$, berarti SEMDSB 20\% memiliki efek yang lebih baik daripada SSDSB $10 \%$.

Kelompok SEMDSB 10\% dan SEMDSB 20\% dibandingkan dengan SSDSB 20\% tidak menunjukkan perbedaan yang signifikan dengan nilai $p=0,969$ dan nilai $p=0,406$. SEMDSB $10 \%$ dan SEMDSB 20\% memiliki potensi yang setara. Kelompok SSDSB 10\% dibandingkan dengan SSDSB 20\% tidak menunjukkan perbedaan yang signifikan dengan nilai $p=0,223$, keduanya memiliki potensi yang setara.

\section{Diskusi}

Berdasarkan hasil penelitian, dapat dilihat bahwa SEMDSB 10\%, SEMDSB 20\%, SSDSB $10 \%$, SSDSB $20 \%$ dapat mempercepat waktu penyembuhan luka. Hal ini disebabkan 


\section{Research Article}

daun Kalanchoe pinnata (Lamk) mengandung senyawa tannin, flavonoid, steroidal glycoside, dan saponin. ${ }^{14}$

Dalam proses penyembuhan luka, flavonoid yang memberikan efek sebagai antioksidan akan menurunkan aktivitas Reactive Oxygen Species (ROS) pada tempat luka. Aktivitas ROS pada tempat luka akan menyebabkan kematian dari sel fibroblas dan sel-sel lain sehingga akan terjadi kematian jaringan. Nekrosis atau jaringan yang mati ini harus dibersihkan oleh aktivitas neutrofil. ROS pada tempat luka akan memperlambat fase inflamasi sehingga luka akut dapat berubah menjadi kronik (Nayak et al., 2009; Mills dan Bone, 2000). ${ }^{10,15}$

Flavonoid dan saponin berperan dalam menurunkan fragilitas kapiler. Penurunan fragilitas kapiler ini akan menyebabkan peningkatan tonus jaringan ikat dan penurunan jumlah isi kapiler yang keluar ke jaringan. Aktivitas ini akan menghambat terjadinya oedem. Flavonoid dapat mengikat ion logam $(\mathrm{Fe})$ dan berikatan dengan protein seperti enzim dan protein struktural sehingga dapat meningkatkan integritas jaringan pada tempat luka. Senyawa saponin meningkatkan koagulasi sel darah merah dan aktivitas hemolitik sehingga dapat menghentikan perdarahan pada tempat luka ${ }^{10,15}$

Tannin berfungsi sebagai astringen dalam proses penyembuhan luka sehingga permeabilitas mukosa akan berkurang dan ikatan antar mukosa menjadi lebih kuat, akibatnya mikroorganisme dan zat-zat kimia iritan tidak dapat masuk ke dalam luka. Tannin juga akan menghambat hipersekresi cairan mukosa dan menetralisir protein inflamasi. Tannin memiliki afinitas terhadap protein sehingga dapat terkonsentrasi pada area luka. ${ }^{15}$

Steroidal glycoside yaitu bufadienolide glycosides akan dimetabolisme oleh sel pada tempat luka untuk memproduksi agen terapeutik aktif yang dapat memiliki efek imunosupresif. Agen terapeutik ini akan menghambat aktivitas ROS yang dapat menyebabkan kematian jaringan dan memperlambat fase inflamasi pada proses penyembuhan luka. ${ }^{10,15}$

Penambahan konsentrasi ekstrak metanol dan serbuk daun sosor bebek menunjukkan hasil yang tidak berbeda, kemungkinan disebabkan karena dengan penambahan dosis, maka jumlah tannin akan semakin bertambah. Kadar tannin yang terlalu tinggi akan menyebabkan terlalu banyaknya astringensi pada membran mukosa sehingga akan menimbulkan efek iritasi. Selain itu, hal ini menunjukkan bahwa konsentrasi serbuk dan ekstrak metanol 10\% merupakan dosis optimal dalam mempercepat waktu penyembuhan luka. ${ }^{15}$

\section{Simpulan}

Ekstrak metanol dan serbuk daun sosor bebek (Kalanchoe pinnata (Lamk)) dapat mempercepat waktu penyembuhan luka. 


\section{Research Article}

\section{Daftar Pustaka}

1. Sjamsjuhidajat, R., Wim de Jong. Luka dan penyembuhan puka. Buku ajar ilmu bedah. Edisi 2. Jakarta: EGC; 2004.

2. Barbul, A, Efron DT. Wound healing. In Brunicardi FC, Andersen DK, Billiar TR, David L et al., eds. Schwartz's principles of surgery. $9^{\text {th }}$ ed. New York: Mc Graw-Hill Book Companies, 2010; p.378-410.

3. World Health Organization. Prevention and management of wound infection. 2004 [cited 23 November 2011] Available from http://www.who.int/hac/techguidance/tools/Prevention and management of wound infection.pdf.

4. Meenakshi S, Raghavan G, Nath V, Ajay Kumar SR, Shanta M. Antimicrobial, wound healing and antioxidant activity of Plagiochasma appendiculatum Lehm. J Ethnopharmacol. 2006;107:67-72.

5. Senthil KM, Sripriya R, Vijaya RH, Sehgal P. Wound healing potential of Cassia fistula on infected albino rat model. J Surg Res. 2006;131:283-9.

6. Kumar B, Vijayakumar M, Govindarajan R, Pushpangadan P. Etnopharma-cological approaches to wound healing-exploring medicinal plants of India. J Etnopharmacol. 2007;114:103-13.

7. Dalimartha, Setiawan. Atlas tumbuhan obat Indonesia. Edisi 2. Jakarta: Trubus Agriwidya; 2008.

8. Okwu DE, Nnamdi FU. Two nvel flavonoids from Bryophyllum pinnatum and their antimicrobial activity. J.Chem. Pharm. Res. 2011;3(2):1-10.

9. Nayak BS, Marshall JR, Isitor G. Wound healing potential of ethanolic extract of Kalanchoe pinnata (Lamk) leaf - a preliminary study. Indian J. Experim. Biol. 2010;48:572-6.

10. Kamboj A, Saluja AJ. Bryophyllum pinnatum (Lamk) Kurz: phytochemical and pharmacological profile: a review. Phcog Rev. 2009;3:364-74.

11. Gupta B, Dermibas A. Methanol and ethanol extract from grass and plants. USA: University of Cambridge; 2010.

12. Putri M. Tanaman hias di pekarangan rumah yang dapat berkhasiat sebagai obat. Jakarta: Balai Pustaka; 2010.

13. Biology/Microbiology Department Owerri. Antimicrobial potency and phytochemicals analysis of Kalanchoe pinnata leaves extract. 2010 [cited 23 November 2011] Available from http://fedpolynek.edu.ng/nacoste /ANTIMICROBIAL POTENCY AND PHYTOCHEMICAL ANALYSIS OF.pdf.

14. Mills S, Bone K. Principles and practice of phytotherapy: modern herbal medicine. Toronto: Churcill Livingstone, 2000. 